\begin{tabular}{|c|l|}
\hline Title & $\begin{array}{l}\text { Comparison of columns of chemically modified porous glass and silica in reversed-phase high- } \\
\text { performance liquid chromatography of ginsenosides }\end{array}$ \\
\hline Sub Title & \\
\hline Author & $\begin{array}{l}\text { 金沢, 秀子(Kanazawa, Hideko) } \\
\text { 永田, 佳子(Nagata, Yoshiko) } \\
\text { 黒崎, 江美(Kurosaki, Emi) } \\
\text { 松島, 美一(Matsushima, Yoshikazu) } \\
\text { 高井, 信治(Takai, Nobuharu) }\end{array}$ \\
\hline Publisher & 共立薬科大学 \\
\hline Publication year & 1992 \\
\hline Jtitle & $\begin{array}{l}\text { 共立薬科大学研究年報 (The annual report of the Kyoritsu College of } \\
\text { Pharmacy). No.37 (1992. ),p.95- 95 }\end{array}$ \\
\hline JaLC DOI & \\
\hline Abstract & \\
\hline Notes & 抄録 \\
\hline Genre & Technical Report \\
\hline URL & https://koara.lib.keio.ac.jp/xoonips/modules/xoonips/detail.php?koara_id=AN00062898-0000003 \\
\hline $7-0095$ \\
\hline
\end{tabular}

慶應義塾大学学術情報リポジトリ(KOARA)に掲載されているコンテンツの著作権は、それぞれの著作者、学会または出版社/発行者に帰属し、その権利は著作権法によって 保護されています。引用にあたっては、著作権法を遵守してご利用ください。

The copyrights of content available on the KeiO Associated Repository of Academic resources (KOARA) belong to the respective authors, academic societies, or publishers/issuers, and these rights are protected by the Japanese Copyright Act. When quoting the content, please follow the Japanese copyright act. 


\title{
Comparison of columns of chemically modified porous glass and silica in reversed-phase high-performance liquid chromatography of ginsenosides*
}

\author{
Hideko Kanazawa, Yoshiko Nagata, Emi Kurosaki, \\ Yoshikazu Matsushima and Nobuharu TAKAI** \\ 金沢秀子，永田佳子，黒崎江美，松島美一，高井信治**
}

Microporous glass (MPG) is a promising material as the packing of high-performance liquid chromatography (HPLC) for its high chemical resistance and for its homogeneous and cylindrical pores. It is stable between $\mathrm{pH} 2$ and 12. The distribution of the pore size is relatively narrow compared with silica. Though chemically modified silicas are the most commonly used packing materials, their pore size distributions are broad and sometimes bimodal.

We prepared octadecylsilyl porous glass (MPG-ODS) and used it as the packing for reversed-phase HPLC. The columns of MPG-ODS have been successfully used for analytical and preparative HPLC of ginsenosides, saponins of ginseng. Two mobile phases of water-acetonitrile were used for the isocratic elutions of water soluble panaxatriols and other less hydrophilic saponins. Recently Petersen et. al reported HPLC analysis of ginsenosides with a $\mathrm{C}_{18}$ silica column. They used a two-step gradient elution of wateracetonitrile for simultaneous separation of six main ginsenosides.

We examined the chromatographic behavior of the saponins and related compounds on a number of columns of chemically modified porous glass (pore size $550 \dot{A}$ ) and silica (pore size $80 \AA$ A and $300 \AA$ ). Though the retention behavior of ginsenosides was similar on the columns examined, the capacity factors of ten ginsenosides on MPG-ODS column were smaller than on silica columns. From the data presented, it is concluded that MPG-ODS column has a number of advantages over conventional silica-ODS columns for the chromatography of ginsenosides. These properties are attributable to the optimal pore size for the molecular size of the saponins on the one hand and to the narrow distribution range of the pore size on the other.

* 本報告は J. Chromatogr., に発表.

** 東京大学生産技術研究所 